\title{
An Analysis of the U.S. Linkage between Most-Favored-Nation Status and Human Rights Issues: Focusing on the Jackson-Vanik Amendment
}

\author{
SANGHAN WANG; \\ Deparmen of Law and Gradiate Sibool of International Studie's, \\ Sograng Unimersity
}

The Linited States has a special interest in buman rights, not only in the human rights of the Cnited States, but also in the human rights of other countries. In particular, the Americans have shoun a very sensitive response aguinst forced labor. Since the enacoment of the McKinley Act of 1890 , which probibited the importation of products made by prison labor, the lnitud Sutes has made afforts to protect the buman righss of the people in trading partner countrips by linking twide with buman rights isstu's. The mast prominent of such measures is the Jackson-Vanik Amendment, which expressly conditions the granting of Most-fatwred-Nation (MFN) statzs by the United States to non-market vonomies on their emigration laws. In pratice, bowever, the Ameudrumt bats been conitrued by snme 17.5 . Lu--makers to mandate a bouder reading, to encompass general human righss byond the free. don to emigrate. This paper does not intend to argue against the LiS. effort to proiect and improve human rights around the world. Houserer, the idea that the U.S. will gmant the MFN status, which at the core lies the principle of non-discrimination, in order to achieve a certain purpose is undoubiedly contrary to free trake, and will form the staring point of witizim of this paper. In addition, this paper will delve into the requiremens of this law and point aus the problems contained in the fackson-Vanik Ameridment.

- This rescarct: paper was sponcored by the geant of Sogang L niversizy, Giaduate School of Internasiona Sudies.

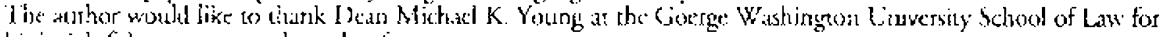
his insightful comments and words of thicontragemen:

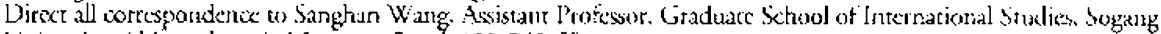
I'niversiry, Shinsu-dong 1. Mapo-su, Seutl, $121-72$, Korea. 


\section{INTRODUCTION}

The United States has a special interest in human rights, not only in the human rights of the Uniced States, but also in the human rights sinations of other countries.' Up until now, Americans have especially shown a very sensitive response against forced labor. This seems to be a reflection of their history, i.e., slavery. Since the enactment of the Mickinley Act of 1890 , which prohibited the importation of products made by prison labor, the United States has made efforts to protect the hunvan rights of the people in trading partner countries by linking trade with human tight issues.

The U.S. policy of containment rowards the Soviet Union during the Cold War transformed into a crusade for human rights in communist countries in the era of dtente. That is, economic interests were subordinated for purposes other than economic reasons. ${ }^{2}$

Perhaps the law with the highest profile, which ties economic tools for the purpose of enforcing human rights in nonmarket economies, is the Jackson-Vanik Amendment." 'I he Jackson-Vanik Amendment expressly conditions the granting of Most-FavoredNation ("MFN") status by the Linied States to nonmarket cconomies on their emrigration laws. ${ }^{i}$ In pracrice, the Amendment has heen constned by some U. S. law-makers to mandatc a broader reading, to cncompass general human rights beyond the freedom to emigrate. This is because the general purpose statement of the Jackson-Vanik Amendment is "to assure the continued dedication of the United States to fundamental human rights."

'T his paper does not intend to argue against the U.S.' efforts to protect and improve the human rights around the world. However, the idea that the U.S. will grant the MFN status which at the core lies the principle of non-discrimination, in order to achieve a certain purpose, is undoubtedly contrary to free trade. As elaborated below, among other things, the Jackson-Vanik Amendment constitutes discriminatory treatment of nonmarket econonues - pertains only to nonmarket economies as opposed to any othet country which may flagrantly violate human rights ciomestically; including the freedom of its citizenry to emigrate."

'For a general discussion of LiS. himan rights policics, we W:. David Clinton. Ihe T'wo Faces of Narional Interest (1994), pp. 235-250.

- Ihuring the period aftes 1946 until the carty $1970 \mathrm{~s}$, there was not much trade betwiten the LI.S. and the Soviet Union. Is the earty 1970 s, the Lnited States and the Sorvet Union encered into a period of détente. As part of the

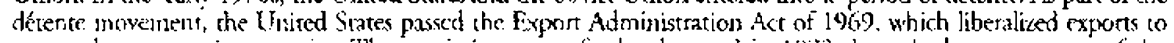
nommarket cionomic countries. The restrictions were further lessened in $19 ; 2$ through the enacment of the

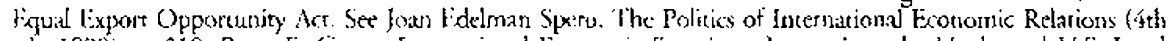
ed., 1990). p. 310; Barry E. Curter. Internarional Economic Sanctions: Improving the Haphazard U.S. Legal

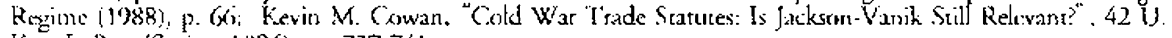
Kan. L Rev. Spring, $1994 ;$ pp. $73 ;-741$.

Sec Wendell L. W'illkie, II, Why Dens MFN Dominate America's China Policy" Beyond MFN: Tade with China acd American Interests (Fdited by Janes J2. Liliey \& Wendell L. Willkie il) (1994), P3.114-115; M.S. Daoudi \& M.S. Dajani, Economic Sanctions: kleals and I:xperience \{1983\%, p. 125.

19 II.S.C. 24,32 .

ld.

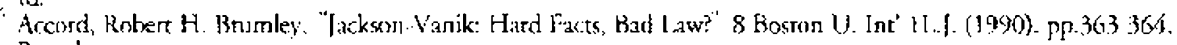
Brumiley notcis:

In the sixtestn years sings its chactment, the Jaskson. Varik Amendurent has been uscd to pressuse the governmentr of ar ill-defined class of nations to conform their internal emigration liws to United States

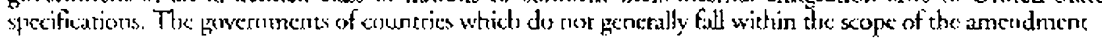


This paper intends to criticize the U.S. Jackson-Vanik Amendment which connects the MFN status to human righes issues. This paper introduces the requirements of this law, and points out the problems the Jackson-Vanik Amendment cuntains in light of the spirit and principle of free trade.

\section{JACKSON-VANIK AMENDMENT}

\section{Requirement}

In 1972, President Nixon entered into the Soviet-American Trade Agreement with the Soviet Union, thereby potentially liberalizing trade testrictions. However, with the advent of the so-called Iackson-Vanik Amendment, the agreement signed by President Nixon never went into effect.

Section 402 of the Tradc Act of 1974 (the "Jackson-Vauik Annendment") sets forth three specific requirements related to freedom of enigration, which must be mer in order for a nonmarket economic councry to become eligible to receive the MFN treatment."

The three main considerations are:

(1) the denial of the right of citizens to emigrate;

(2) the imposirion of onerous exis fees for emigracion: and

(3) the infusision of tuxes, fues, or fincs on citizens who express a desire to leave the country."

The President of the United States may waive the freedom-of-emigration requirements of that title and grant the MFN sratus to a nonmasket economic country if he/she determines that doing so will substancially promote the freedom-of-emigration objectives in Title IV of the 1974 Trade $\mathrm{Act}$. Furthermore, there must be a bilateral commercial agrecment providing reciprocal MF. N starus, which is in force between the United States and the monnarket economy. "The bilatemat agreement musr contain a number of statutorily mandated provisions. Under Sections $405(\mathrm{c})$ and $407(\mathrm{c})$ of the 1974 Trade Acr, a trade agreement with a nonmarker economic country and a Presidential proclamation granting the $\mathrm{M}$ F $\mathrm{N}$ status can rake effect only after enactment of a joint resolution of approval." A bilateral rade agreement between the affected state and the Unired States providing for the mutual MFN status will be valid for up to three years. ${ }^{13}$ After the throe-

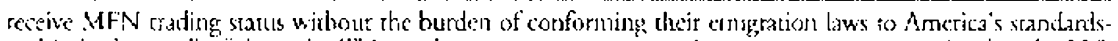

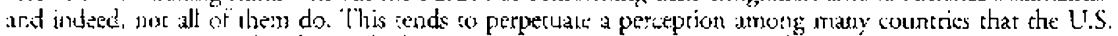

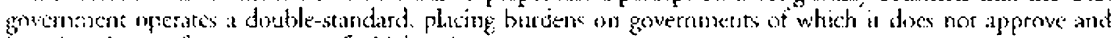
ignering abuses of governitnenes of whict: if does approve.

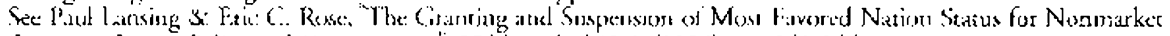

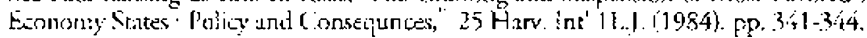

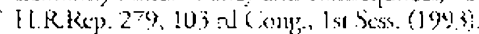

I) II.. ( : 2432

$14 \mathrm{~kJ}$.

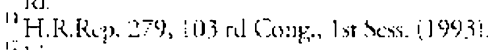

"li.

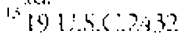


rear period expires, the MFN status will be subject to automatic renewal based upon the President's discretion and pending no Congressional override. ${ }^{14}$

\section{Cases}

\section{(1) The Soviet Union}

The lackson-Vanik Amendment caused an immediate problem because of the bilateral agreement, which was already signed between the Soviet Union and the U.S., had not concemplated such a provision. In 1972, President Nixon had negotiated and signed a bilateral agreement with the Soviet Union, subject to an implementing legislation by Congress, in the hopes of increased trade in the period of detente. ${ }^{15}$ Subsequently, in 1973. Nixon sought the necessary legislation by asking to have Congress to pass the Trade Reform Acr, which would permit the extension of the MFN treatment to nonmarket economic countrics. "it

When the aforementioned bill came before Congress, Senator Henry Jackson and Representative Charles Vanik sought to have the right to emigrate put in as a pre-condition for the MFN rreatment for the Soviet Union. Initially, with respect to the Soviet Union, Kissinger told Senator Jackson that "we have been assured the following criteria and practices would henceforth govern immigration," 19 and listed the following:

No punitive actions against potential emigrants, no unreasonable impediments to enigration, systematic processing of cases and sympatheic consideration of problem cases. ${ }^{19}$

Apparently, Jackson wrote back, detailing his understanding of the Sovict assurances, that 60,000 emigrants per year would be the yardstick with which to determine whether the Sovier Union had satified its assurance. ${ }^{2 i}$ Despite the optimistic tenor of the foregoing exchange regarding Soviet willingness to abide by L.S. imposed preconditions for receiving the MIN treatment, the Soviet Union had apparently not given any assurances $^{21}$ as Kissinger said at the time:

The Soviet Government informed us that if statements were made by the L.S., in the terms required by the trade act, conceming assurances by the Soviet Government regarding matters it considers within irs domestic jurisdiction, such statements would be repudiared by the Soviet Government... The Soviet Government states that it does not intend to accept a trade status that 
is discriminatory and subject to potinios conditions, and accordingly, that it will nor put into force the 1972 ' lade Agreenent."

1'he Jackson. Vanik experience can be described as a practical failure with respect to the Soviet Lnion, in a number of areas. First of all, it is noted that the amendment did not help but may have, in fact. worsened the enigration situation of Jews in the Sovier Union." While there may have been a reduction of restrictions on emigration while the Jackson-Vanik Amendment was being contemplated, emigration has been sharply curwilcel after the enactment. ${ }^{2 i}$ Also, from a monetary perspective, the Ancondment cifecriwely crushed the L.S. hopes of the lend-lease settement which had been negoriated between the U.S. and Soviet Lnion. This would have provided for the repayment of a $\$$ 674 million outstanding World War ll koan by the Soviet Union.

As a result of the Jackson-Vanik Amendment, the U.S. was slow to react to the business opportunities affurded by the Sorict Union's aggressive posture to seek investment and business opportunities from ntarket economies during the latter half of the $1980 \mathrm{~s}$. In a statement before the House Commitec on Foreign Afairs, Thomas A. Simons, Jr., Depury Assistant Secretary of Srate, explained that part of the U.S. reticence to jump at the opportunities were driven hy human rights issues in the Jackson-Vanik Atnendnent. ${ }^{26}$ Among other things, the Jackson- Vanik Amendment inflicts an economic price in terms of sacrificing economic opportunities with nonmarker economic countries in return for the nonmarket economic country's improvement of emigration policies. There are several ofwioms flaws to such an approach. First, it is not at all clear whether this approach is in faxt the best, or even at rational, approach to induce the: improvement of emigation rights in the target country. The Amendment appears to have had dubious success in promoting its objective of improving Sovict emigration laws. Second, the Jackson-Varik Amendment is an offensive incarnation of a discriminatory contra-free trade tool. It is discriminatory since only nonmarkct economies are subject ro it. Thus, the U.S. may be criticized for upholding a double standard for human rights in terms of emigration -. one applicable to nonmarket cconomies and anorber to market ecomomics." Third, it is evident that the Jackson-Vanik Amendment's human right to

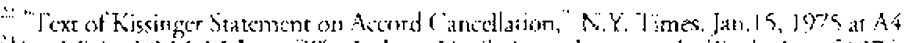

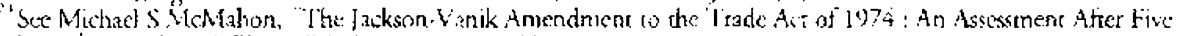

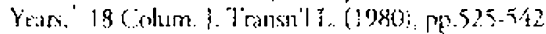

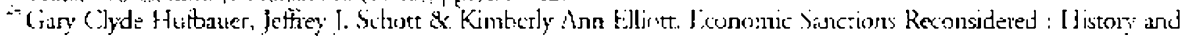
Cusent Policy i $1085, \mathrm{p}$. 516.

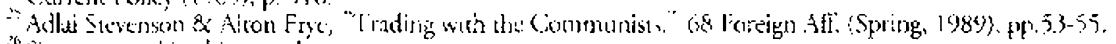

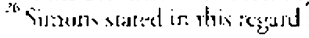

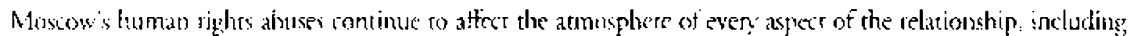

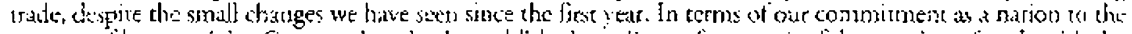

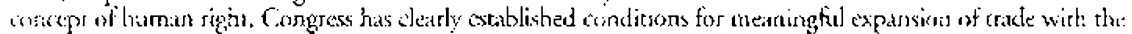

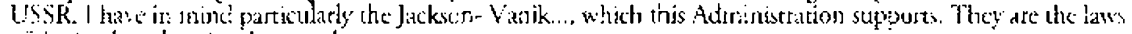

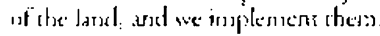

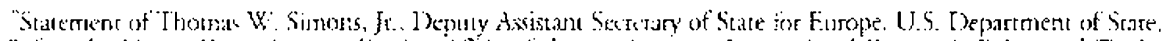

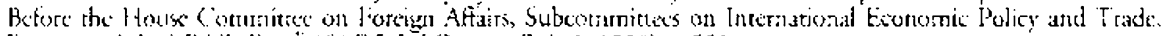

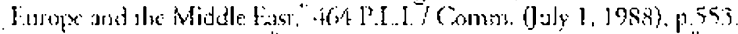

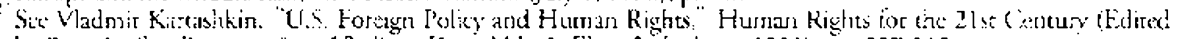

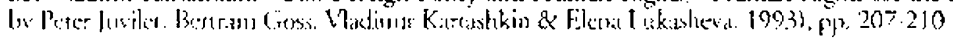


emigrate pre-condition damages the pursuit of free trade because the Amendment directIy conditions what ought to be a universal principle - i.e., the MFN - on a specific moral and political issue. Fourth, it can be argued that the ideal of human right should not be exploited for economic purposes. In other words, cynics of the Jackson-Varik Amendment view it as a rool for the U.S. to gain leverage against the target country in cconomic neyotiarions. The concern is that the issue of human rights could be subverted as a rool for economic interests. ${ }^{28}$ Fifth, by linking crade issues with human rights, the U.S. runs the risk of reciprocation from other nations. For example, would not the Soviet Union, or any other nonmarket economic country can justify in making political demands to the U.S., by tying them to economic incentives. ${ }^{2(3)}$

In sum, for the reasuns enumerated above, the U.S. should rescind the Jackson-Varik Amendment. Indeed, there are promising signs in this regard. In tecent years, the L.S. has considered removing the application of the Jackson-Vanik requirement with Russia, in partial recognition that it would increase trade. Russia and the Lniced Srates issued a joint statement on economic partnership wherein latter administration promised at least to attempt to remove Russia from the reaches of the Jackson-Vanik Amendment.

\section{2) Romania}

Congressional debates to deny the MFN status to Romania on the basis of the Jackson-Vanik indicate an attempt to broaden the applicability of Jackson-Vanik from the Jews' right to emigrate in the Soviet Union, to general human rights issues in all nonmarket economies.

A reading of the Jackson-Vanik Amendment indicates that the specific human rights requirement relates to the "right or opportunity to emigrate." ${ }^{30}$ However, there is also a general purpose statement which states the Jackson-Vanik Amendment is "to assure the continued dedication of the United States to fundamental human rights."

The potential for conflicting interpretations of the Jackson-Vanik Amendment led to debates on the issue in the context of Romania in 1986. Both the House and the Senate requircd the President to reccive assurances regarding Romania's treatment of ethnic and religious minoritics; ${ }^{32}$ as elaborated by Senator William Armstrong at the time:

While ]ackson-Vanik uses the specific right of free emigrarisn by which to measure progress in human rights, it would be negtigent to ignore Romania's human rights abuses in ocher areas.

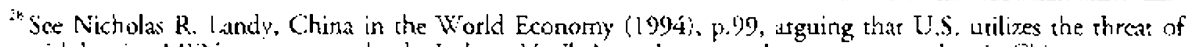

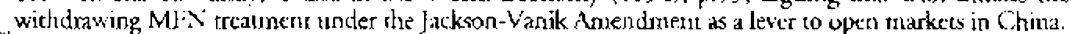

"See Harold T. Berman, "The Inieraction of Law and Politics in Trade Relations betwexen rhe (Jrited States and the Sovie Linion." S ]. Int' 1L. \& I'al'y (\{975\}, pp, 233-235. Bkinan recorically quextions and conments :

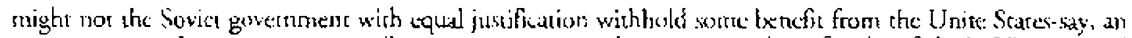
agrecmenc to ieduce armancents-until our government pardons persons who refused to fight in Vijetram and

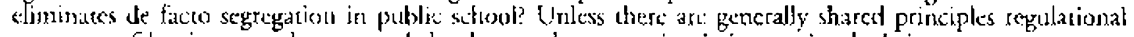
reponses us fel grievances, there ate ondy be chados and opportunism in international relacions.

1) Li.S.C. 2432 (3) (1) i 1 $19 \times 8$ ).

"Id.

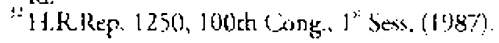


This is particularly true in light of the fact that the United Sates Helsinki Watch Committec, among athers, has called the Romanian Government "onc of the most cgregious offenders of human rights in Fastern Furope."

Expanding the scope of human rights issues beyond the freedom of emigration was not without its critics. Many critics focused on the language of the Jackson-Vanik agreement and argued that human rights concerns should be limited to emigration issues when it cance to the issue of granting the MFN status to nonmarket economies."

In the midst of Congtensional debates about the witholding the MFN status doe wo Romania's persecution of its minnrities, on July 3,1988, the MFN status was removed by the mutual consent of Romariia and the L:S."

The Romanian case illustrates that the Jackson-Vanik Amendment can be politically exploited by lawmakers to apply to other human rights abuses in nonmarket economies. beyond the abuse of the heman right to cmigrate. This susceptibility to broad interpretation magnifies the discriminatory nature of the act. In other words, if the broad interprecation is allowed not only will the U.S. discriminate berween matket and nonmarke economies when it comes to the right to emigrate, the U.S. may discriminate betwecn nonmarket and market economies when it comes to any human risht under the broader intcrprecation advanced by a few lawmakets.

\section{(3) Hungary}

The Hungarian case presented the first time in a report of assurances, in which the President acknowledged that discussions concerning emigration problems with a nonmarket economic country took place. Also, this was the first time that a nonmarket economy commited officially to the L'S. that it would work cowards solving emigration problems." "Iresident Carter reported that Hungary's actions on emigtation were consistent with U.S. policy. "The I Jouse and the Senate Commitrees also conduded that the

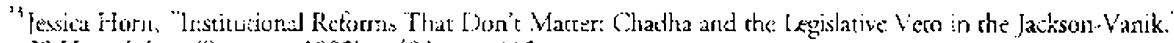

2) Hars. J. Leg. (Sum tonce 1902). p.483. nok 115.

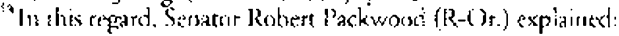

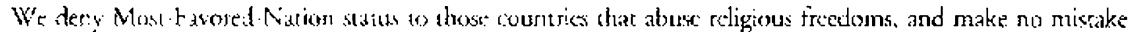
abour is the conciuct ot Rom,aniz, when it comes ro religious froedon is brutish, boorish. depiorable, disgus?ing. There is uks unestion dhout that. Bust the Jackson-Vanik Amendment and the extension of Must-Fovored-

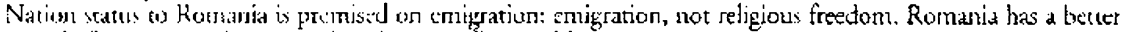

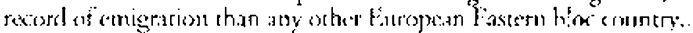

Id. p. 481 , note 118 .

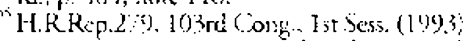

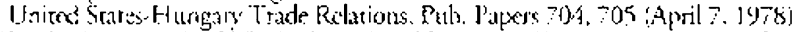

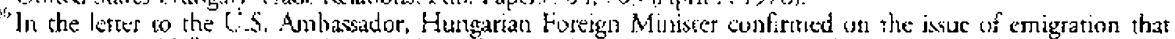

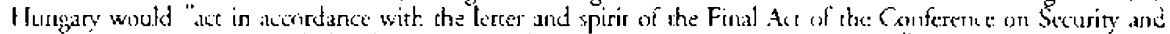

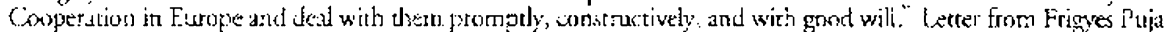

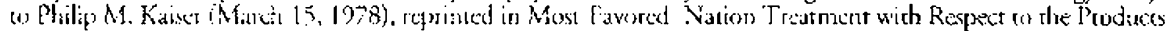
of Huneary. Hearing on H.R Com. Res 555 Hefore the Subcon:m, On Irade of the House (amm. On Ways and

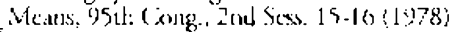

With this resper. P'osiden: (arter mponed:

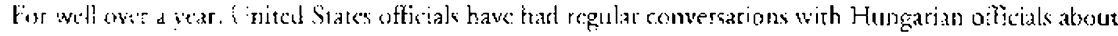


receipt of Hungarian assurances fully met the wajver requirements of the 'liade Act. ${ }^{34}$

The approval by Congress of a commercial agrement would indicate implied acceptance of the repor of assuranices and would confer MFN status to the nonmarket conomy. However, Congress could nor be cerrain that the foreign government was aware of the importance placed by Congress on the emigration objective, nor could it be certain that any lines of communication had been established through which problem cases could be channeled. Such an interpretation amounts to a complete cession to the Executive of the obligarion to implement the emigration objective of the Amendment. ${ }^{\text {"n }}$

\section{(4) Chind}

The MFN status was first granted on February 1, 1980 to the People's Republic of China. "It has been subsequently renewed every year through the Presidential waiver. 'There is a continuing public policy debate regarding the propriety of linkage berween human rights issues and the most-favored nation grant clause in the context of the Urited Statcs' trade relationship with China.

With respect to the issue of whether the MFN status should be withheld on the basis of human rights denial by China, particularly in light of the Tiananmen Square massacre, ${ }^{4.5}$ there may have been grounds to do so under the strict interpretation of Jackson-Vanik's freedom of emigration requirement. ${ }^{\text {th }}$ However, a precedent for attempting to expand the issue to general human rights had already been set with the Romanian case. ${ }^{45}$ Indecd, although there were strong Congrexsional protests against extending the

I lungarian emigration law, policy and practices, and about the resolution of individual cases. The Hungarian Governmene has stressed that it intends to continuc dealing with emjgration matters in a responsible and Intmarjiadian way.

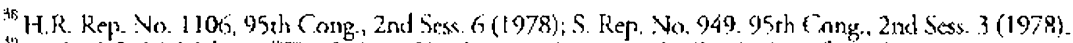

"Michael S. Movalion, "The Jackson-Vanik Amendment to the liade Act of 1974 : An Assessment Atier Five

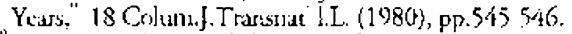

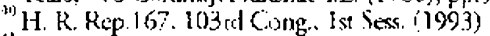

${ }^{41} \mathrm{ld}$.

"Sce. generally, Robert I. Drinatk, S.J. \&. Teresa T. Kuw, "The 1991 Battlc for Human Rights in China," 14 Hum. Ris. Q (1992), (p.2)

"See Jsnnifer E. Morris, "Y Juman Rightss Violations During the Tiananmen Syuare Massacre and the Precedents (Jbliging United Srates Response. 13 Cardozo L. Rav. (December, 1991), Pp. 1375-1378 who recounts the incident as tollows:

Artiough the actual number of civitians killet during the massacte is uncertain, an account distributcot through an undergrournd computer network with China indicates approximancly 10.000 people where ar rested and 28 . 790 were wounded berween June 3 and June 9

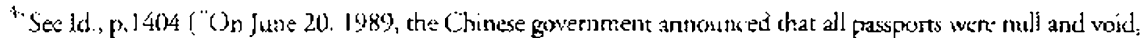
and those wishing (6) travel would neal (o apply for new pasports ar police stations amind the country")

${ }^{4 i}$ In this regard, Representative (Chris Smich (K.N.J.) noted:

As I think Mernlers know, while Jacksur-Varik specifically focuses on emigration figures, the level of complianse with internatiunally recognized humas rights scandards musa he included in our criceria. I think part of the pecesdence tor that was cur work in the mid-1980's on suspending and then perhaps even tevoking MIN tor Romania.

Most Fawored Vation sratus for the I'eopie's Keputlic of Chaina; I learing betore the Subcomm. On Humas Rights and Intercutional Organuzations, Asjan and l'acifu Aflairs, and on lnternational Economic l'olicy and "Trade of the House comm. "On Forrign Affairs, 101" Cong. $2^{\text {nt }}$ Sess. 4 (1990), cited in Jessica Korn, : Insriturional Reforms th:at Dorit Macter: Chadha and the Legislative Veto ir Jackson-Vanik," 29 Harv. J. Leg. (1992), p.486. whe 125 . 
MFN starus to China, in 1991 and 1992, President Bush vetoed Congressional attempts to oppose the extension of the MFN starus to China on human rights grounds, stating that attaching human rights conditions to trade agreements would be counter-productive to the relationship with China. In 1992, while the House overrode the veto, the Senate Eailed to do so.

While the Jackson-Vanik Amendment is a law, which the exccurive branch cannor alter, the framework implementing the Jackson-Vanik Amendment provides considerable discretion to the I'resident. The Jackson-Vanik Amendment permits the President, on a yearly basis, to waive the freedom to emigrate requirement with respect to a particular nontrarket cconomy if certain conditions are met." Annong other things, the I'resident muse receive assurinces and report to Congress that stech a waver will substantially promote the objectives of the Jackson-Varik Amendenent." The Presidential waiver is not effective if it is opposed by a joint Housc and Senate resolution. ${ }^{\text {is }}$

Incidencs such as the Tiananmen Square massacre are abominable, and no nation on earth should resure to such measures. Such incidencs evoke an emorional response of outrage by humanity at large. However, the criticisms of linkage beween human righes issues to monmatket coonomies, noted carlice in the discussion of the former Sovict Union, apply cytally in this ase as wdl.

On May 1993. Presiden (Xinton signed an executive order 12850, which waived the human rights recquirenent for (hina for another year."

Athough he stated that, "Whereas the Congress and the American people have expressed deep concern about the appropriateness of unconditional most-favored nation... crading status for China... which I share particularly with respect to China's recoral on hunan rights," Clinton put off the issue for another ytar, making references thar China's human rights record would be revisited in $1294^{\text {5n }}$

However, in 1904, the Prexident putblicly announced that China's MFN status would be diyoted from human rights issues." As of 1998, the Clinton administration has continued ics policy of delinking human rights issues with China's MHN status. 'The above administrative position may be a significant step to ultimately abandoning the JacksonVanik requirenent, although the exccutive branch policy may easily change, particularly if a tew administrution takes office.

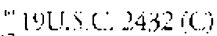

it.

id.

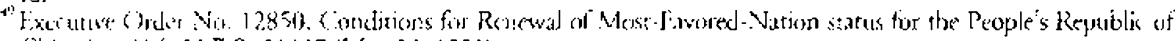

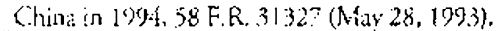

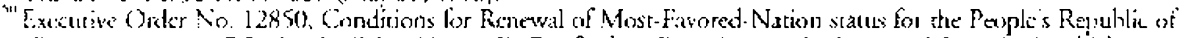

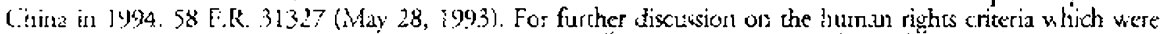

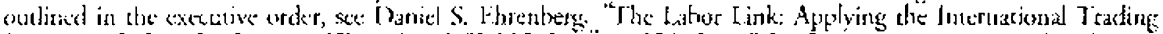

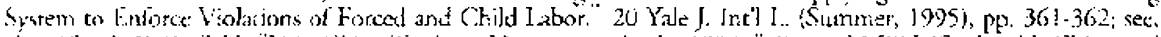

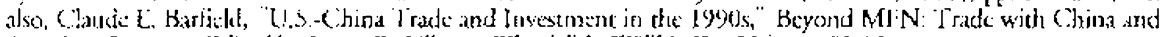
American Inuerests. Edited by Jartes R. [idley \&. Wendell 1. Wilkic II, 1994. pp. 58.72.

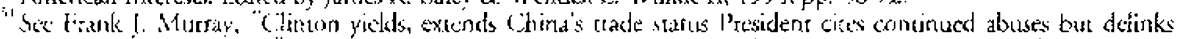

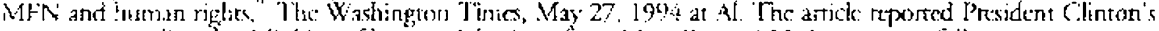

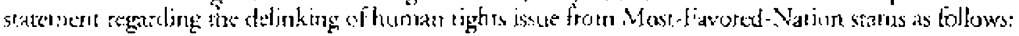

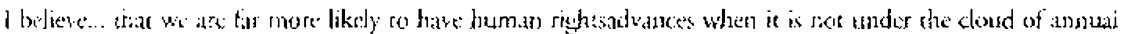

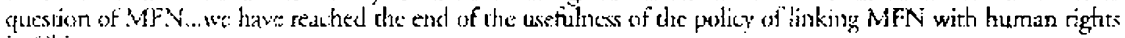
in Chisla. 


\section{CONCIUSION}

To date, the United States has played a leading role in political, economic and social aspects. Is took the initiative in establishing the international organizations which pursuc free rrade. The U.S. representative, who participated in the negotiations, signed the final draft of these organizations and agrced to comply with the spirit and principles of free trade, which the U.S. Congress subseouently ratified. Therefore, the U.S. is, with no doubt like other countries, imposed with a legal duty to comply wholly with the principles of free trade. In consideration of its self-declared position as a world leader, it is a matter of course that the U.S. should act as a role model to other countrics in observing international ruks.

There is now more than ever a need, for revisiting the old rules, discarding ones that are anachronistic, and adopting new ones to adjust to the changing times. In this regard, as important as emigration rights are, this paper would note that the Jackson-Vanik Amendment is an anachronism which ought to be decoupled from trade issucs.

The Jackson-Vanik Amendment has caused a number of internal and external problems to the U.S. since its enaciment. Furthermorc, although this law appears on its surface so sccure human rights protection, it is possible to argue that the real incention of the U.S. is to maximize its economic profits by linking the MFN status with human rights issittes.

This paper has tried to bring attention to the Jackson-Vanik Amendment, which violates the free rade principles, including the principle of nondiscrimination. The repeal of the Jackson-Vanik Amendnent is necessary to engage in a coherent U.S. policy based on economic principles, apart from the issue of ennigration rights.

\section{RFFERENCES}

Barfield, Claude E. 1994. "U.S.Chind Tradc and lnvestment in the 1990s." In Beyond MFN: Trade with Chita and American Interests, eds. James R. Lilley and Wendell L. Willkie II. Washington, D.C.: AEI Press.

Berman, Harold J. 1975. "The Interaction of Law and Politics in Trade Relations between the United States and the Soviet Lnion." Joumal of Intemational Lau and lodicy, vol. 5: 231-235.

Brunlky, Robært H. 1990. "Jackson-Varik: Hard Facts, Bad I aw:" Buston Inivenity Intemacional Law loumal 8(Fall): 363-364.

Carter, Rarry E. 1988. Intemational Economic Sanctions: Improving the Haphazard U.S. Legal Regime. Cambridge: Cambridge University l'ress.

Clincon, David W. 1994. The Tuo faces of National Interest. Baton Rouge, Ia.: Louisiana State Úniversity Press.

Cowan, Kevin M. 1994. "Cold War Trade Satutes: Is Jackson-Vanik Still Relevant?" University of Kinsisar Law Review 42(Spring): $737-741$.

Drinan, Robert F., and Teresa T. Kuo. 1992. "The 1993 Batte for Human Rights in China," Hitmar Rights Quarterity, sol, 14:21.

Ehrenterg, Daniet S. 1995. "The labor Link; Applying the Incernational "Irading System to Enforce Violations of loorced and Child L.abor." Yale Joumal of Inzemational Law 20 
(Sumncr): $361 \cdot 362$

Horm, Jessica. 1992. "Insuitutional Reiorms That Don'r Matter: Chadha and the Legislative Veto it the Jackson-Vanik," Hanurd Joumal of Legislation 2\%(Summer): 483, 486.

Hutbucr, Gary C.. J. J. Schotr and K. A. Elliot. 1985. Economic Sancions Reconsidered: Hitory and Cumem Poltcy. Wishington, D.C.: Institute for Internarional Economics.

Kartzshkin, Vladirnir. 1993. "L.S. Forcign Policy and Hurman Rights." Iluman Kights for the $2 f^{t}$ Century: Foundations for Responsibie Hope, cds. P. Juviler, B. Gross, V. Kartashkin and E. Lukasheva. Armonk, N.Y.: M. L. Sharpe.

Landy, Nichals R. 1994. China in the World Economy. Washington, D.C.: Instirute for Incernationa! Economics

Launsing, Paul, and E. C. Rose. 1981. "The Cranting and Suspension of Most-Favored-Nation Star!us for Nonmarket Economy States: Policy and Consequences," Hariard Intemational Lau foumal 25 (Spring): $341 \cdot 344$.

McMahon, Michacl S. 1980. "The Jackson-Vanik Amendment to the Trade Acr of 1974: An Assewsment After live Yeurs." Columbia joumal of Transmational Law, wol. 18: 525-542.

Morris. Jennifer F. 1991. "Human Rights Violations During the I iananmen Square Massacre

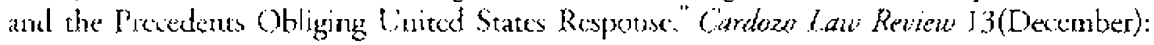
13751378

Murray: Frank J. 1994. "Clinton yiedds, extends China's trade stans President cites continued abuses but 'delinks' Mit and human rights," The Washington Jimes, May 27.

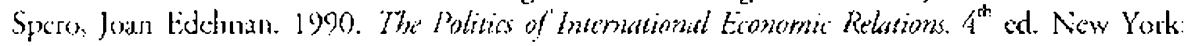
Saint Mantin 's l'ress.

Stevenson, Adlai, and Aloon Frye. 1989. "Trading with the Communists." Foreign Affairs 68 (Spring): 53-55.

Wilkie: Wondell 1. II. 1994. Why Does MFN Dominate Americis Shina Policy?" In Beyond MFW: Trade uith Chind and American Interest, cds. James R. Lilley and Wendell $\mathbf{L}$. Wilkite Il.

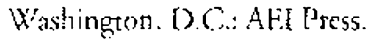

